\title{
The impact of groundwater discharges on mercury partitioning, speciation and bioavailability to mussels in a coastal zone
}

\author{
Fabien, J. G. Laurier ${ }^{a}$, Daniel Cossa*, Charlotte Beucher ${ }^{b}$ and Emilie Brévière ${ }^{c}$
}

\author{
Institut français de recherche pour l'exploitation de la mer, BP 21105, F.44311 Nantes cedex 03, France \\ ${ }^{a}$ Present address: Chesapeake Biological Laboratory, University of Maryland, Solomons, MD 20688-0038, USA \\ ${ }^{\mathrm{b}}$ Present address: Marine Biological Laboratory, University of California at Santa Barbara, Department of ecology, \\ Santa Barbara, CA 93 106, USA \\ ${ }^{\mathrm{c}}$ Present address: SoLAs International Project, University of East Anglia, Norwich, NR4 7TJ, UK \\ *Corresponding author (cossa@ifremer.fr)
}

\begin{abstract}
The Mussel Watch program conducted along the French coasts for the last 20 years indicates that the highest mercury concentrations in the soft tissue of the blue mussel (Mytilus edulis) occur in the maritime Caux region (the eastern part of Seine Bay on the south coast of the English Channel). This region is characterized by the presence of intertidal and submarine groundwater discharges, and no particular mercury effluent has been reported. Two groundwater emergence systems (Etretat and Yport) in the karstic coastal zone of the Caux region were seasonally sampled to study mercury distribution, partitioning and speciation from these sources. Samples were also collected to compare speciation changes during freshwater-seawater mixing between these "subterranean" or "groundwater" estuaries and the adjacent Seine estuary. The mercury concentrations in the soft tissue of mussels from the same areas were monitored seasonally at the same time.

The groundwater springs showed similar total mercury concentrations for bulk water samples $(\mathrm{HgTD}+\mathrm{P})$. The means of the dissolved $(<0.45 \mu \mathrm{m})$ mercury concentrations (HgTD) were $0.99 \pm 0.15$ ng l-1 and $0.44 \pm 0.17 \mathrm{ng} \mathrm{l}-1$ at Etretat as at Yport respectively. High HgTD concentrations were associated with strong surface runoff over short water pathways during storm periods, while low concentrations were associated with long groundwater pathways. Mean particulate mercury concentrations were $0.22 \pm 0.05 \mathrm{ng} \mathrm{mg}-1$ and $0.16 \pm 0.10 \mathrm{ng} \mathrm{mg}-1$ at Etretat and Yport respectively, and decreased with increasing particle concentration as a result of dilution by soil erosion. Groundwater mercury speciation was characterized by high reactive-to-total mercury ratios in the dissolved phase (HgRD / HgTD: 44 - $95 \%$ ), and undetectable total monomethylmercury concentrations (MMHg <8 pg l-1). The HgTD distributions in the Yport and Etretat mixing zones were similar (overall mean concentration of $0.73 \pm 0.21 \mathrm{ng} \mathrm{l}-1$ ), but higher than those measured in the adjacent heavily industrialized Seine estuary (mean: $0.32 \pm 0.13 \mathrm{ng} \mathrm{I}-1$ ). In the waters along the Pays de Caux dissolved monomethylmercury (MMHgD) concentrations varied from 9.5 to $13.5 \mathrm{pg} \mathrm{l-1}$ (2.4 to $7.8 \%$ of the HgTD). Similar levels were measured in the Seine estuary (range: 12.2 - $21.1 \mathrm{pg}$ l-1; 5.5 - $11.6 \%$ of the HgTD). The specific biogeochemical characteristics of these underground karstic estuaries seem to promote higher dissolved mercury in coastal waters. While the high turbidity zone of the Seine estuary acts as a dissolved mercury removal system, the mixing zone of the Caux region receives the dissolved mercury inputs from the groundwater seepage with an apparent $\mathrm{Hg}$ transfer from the particulate phase. After normalization for minimizing the effect of the seasonal variations of the soft tissue weight, the mercury contents of mussels from Etretat and Yport exhibited significantly higher values than those found in the mussel from the mouth of the Seine estuary. We argue that this difference reflects the mercury distribution in the water and that the dissolved phase of the groundwater estuaries is a significant source of bioavailable mercury for mussels.
\end{abstract}

Keywords: Mercury, Estuaries, Seepage, Speciation, Mussel 


\section{Introduction}

The existence of groundwater seepage in coastal zones has been known for many years. It is now recognized that this process represents an important pathway for continental material inputs to the sea (e.g., Burnett and Turner, 2001). The Scientific Committee on Oceanic Research (SCOR) and the Land-Ocean Interactions in the Coastal Zone (LOICZ) Project of the International GeosphereBiosphere Program (IGBP) have established a working group of experts to examine questions relating specifically to groundwater discharge in the coastal zone (Gordon and Boudreau, 1995; Gordon et al., 1996; Boudreau et al, 1996). Like surface water, groundwater flows along a gradient, thus entering directly into the sea wherever a coastal aquifer exists. Moreover, an aquifer can extend for a considerable distance from the shore beneath the continental shelf, with discharges into the ocean occurring at outcrop points. While the magnitude of such discharges may be relatively minor in areas dominated by river flow, recent studies have shown that groundwater occasionally accounts for a significant fraction of freshwater outflow (Burnett and Turner, 2001; Moore, 1996; Cable et al., 1996). Because groundwater composition is typically different from that of the receiving coastal waters, submarine groundwater discharges may be significant as a pathway for dissolved elements and substances (Johannes, 1980; Corbett et al., 1999 and 2000). Previous studies have presented convincing evidence indicating that direct groundwater flow into the ocean can be significant for overall nutrient balance in some areas, and that groundwater discharge may be important, at least in some cases, for geochemical budgets and ecological effects (Johannes, 1980; Moore, 1996). A few recent studies have dealt with trace elements (e.g., Spinelli et al., 2002; Charette and Sholkovitz, 2006; Charrette et al;, 2005).

The coastline of the Pays de Caux (France), on the south shore of the English Channel, is the site of intertidal and subtidal ground water springs from karstic sources (Fig. 1) (Lechevalier, 1998). Since 1979, the French Mussel Watch Program (Réseau National d'Observation, RNO; http://www.ifremer.fr/envlit/surveillance/index.htm) has sampled bivalve mollusks on a quarterly basis along the French coasts and measured trace metals including mercury in the soft tissues of the animal (Claisse, 1989; Claisse et al., 2001). At the 110 sampling stations along the French coasts, mussels at sites in the Caux region have the highest mean levels of total mercury. The logical explanation for these high concentrations would be inputs from the adjacent heavily industrialized Seine River estuary (Fig. 1). However, the mercury concentrations in mussel soft tissue have been systematically higher in mussels from the Pays de Caux since 1989 (Fig. 2). In addition, the temporal trends of mercury concentrations in mussels from the Caux region and the mouth of the Seine estuary, even though they depict in-phase seasonal variations, have differed over the past ten years (Fig. 2). The temporal concentration distribution patterns in mussels from the two adjacent regions suggest distinct mercury sources or differences in the chemical processes governing the mercury concentrations and bioavailability in the Seine estuary and the groundwater estuary of the Pays de Caux. Data are presented here to test these hypotheses.

\section{Sites and methods}

\subsection{Sites}

The northern shore of the Seine estuary and bay consists of a chalky/calcareous and flint aquifer covered by silt and a thin layer of clay. The $12,000 \mathrm{~km}^{2}$ surface area corresponds to the SeineMaritime region, including the Pays de Caux (Fig. 1). Average aquifer thickness (saturated and unsaturated) is 100 meters. Both aquifer and karstic type systems feed the water table, with fast and slow flow rates respectively, depending on fracture size. To reach the coastal area, rainfall follows three distinct pathways: (i) surface run-off and direct inflow to the seashore (mainly via cliffs), (ii) fast flow through the karst via karstic subsidence and fractures, and (iii) slow percolation through superficial layers and the aquifer (Fig. 3). The part of the aquifer studied, in the Pays de Caux, is characterized by a topography that cuts the upper part of the water table at the near-shore, leading to points of groundwater emergence (Fig. 3). Two cases of groundwater emergence in the intertidal zone northeast of Le Havre (Fig. 2) were studied: Etretat (Porte d'Amont) $\left(49^{\circ} 43^{\prime} 016 \mathrm{~N} ; 0^{\circ} 12^{\prime} 767 \mathrm{E}\right.$ ) and Yport $\left(49^{\circ} 44^{\prime} 740 \mathrm{~N} ; 0^{\circ} 19^{\prime} 640 \mathrm{E}\right)$. Estimated overall freshwater discharge is $200 \mathrm{I} \mathrm{s}^{-1}$ for Etretat and $1,500 \mathrm{I} \mathrm{s}^{-1}$ for Yport (de la Querrière, 1999). Assuming an annual renewal of the aquifer of $2.510^{9} \mathrm{~m}^{3}$ (de la Querrière, 1999), groundwater discharge to the coastal area of the Caux region would be about $80 \mathrm{~m}^{3} \mathrm{~s}^{-1}$, which is equivalent to the adjacent Seine river discharge during dry periods. 


\subsection{Sampling}

Samples were obtained monthly between March 2000 and February 2001 from both sampling sites (Yport and Etretat). Additional water samples for MMHg analyses are from a cruise in the Seine bay and along the Caux shoreline in February 2000 (Laurier et al., 2003a). Surface water samples were collected in acid cleaned 2 I Teflon ${ }^{\circledR}$ bottles stored at $4{ }^{\circ} \mathrm{C}$ and then filtered $\left(0.45 \mu \mathrm{m}\right.$, LCR Millipore ${ }^{\circledR}$ membranes) and analyzed within $48 \mathrm{~h}$. Thus, in the following manuscript, the operationally defined "dissolved" refers to the fraction $<0.45 \mu \mathrm{m}$. Soil samples were taken from the top of the cliffs, towering $20 \mathrm{~m}$ above the sea, in polypropylene bags and stored frozen before analysis. Mussel sampling included a total of 292 individuals (Mytilus edulis), 25 to $60 \mathrm{~mm}$ in shell length, collected monthly from both the Yport and the Etretat areas. Mussels were stored in polyethylene bags at $-15^{\circ} \mathrm{C}$ until freeze-drying and analysis. Polyethylene gloves were used for water and mussel handling operations. All Teflon ${ }^{\circledR}$ and plastic ware were acid-washed (3 days in $50 \% \mathrm{HNO}_{3}$, then 3 days in $10 \% \mathrm{HNO}_{3}$ at $50^{\circ} \mathrm{C}$ ) and rinsed several times with Milli-Q ${ }^{\circledR}$ water prior to use. Cleaned Teflon ${ }^{\circledR}$ bottles were filled with Milli- $Q^{\circledR}$ water acidified with $\mathrm{HCl}\left(1 \% \mathrm{v} / \mathrm{v}\right.$, Seastar $\left.{ }^{\circledR}\right)$ and stored in double polyethylene bags until use.

\subsection{Analyses}

Samples were analyzed for dissolved "reactive" or "easily reducible" mercury $\left(\mathrm{HgR}_{\mathrm{D}}\right)$, total dissolved mercury $\left(\mathrm{Hg}_{\mathrm{D}}\right)$, total particulate mercury $\left(\mathrm{Hg}_{\mathrm{P}}\right)$ and dissolved monomethylmercury $\left(\mathrm{MMHg}_{\mathrm{D}}\right)$. In the marine environment, the operationally defined $\mathrm{HgR}_{\mathrm{D}}$ is thought to consist of labile organic mercury complexes and inorganic mercury complexes, including chlorocomplexes (Mason and Fitzgerald, 1993; Lamborg, 2003). All mercury species were detected by cold vapor atomic fluorescence spectrometry (AFS) after reduction to $\mathrm{Hg}^{\circ}$ (Bloom and Fitzgerald, 1988), using a Merlin instrument (PSAnalytical ${ }^{\circledR}$ ). Dissolved gaseous mercury (DGM) was collected by bubbling with mercury free argon at a flow rate of $300 \mathrm{ml} \mathrm{min}^{-1}$. The gas was stripped of its mercury by passage over a gold-coated sand trap after a drying step on a soda lime column. The $\mathrm{Hg}$ was desorbed from the trap by pyrolysis under an argon flow rate of $150 \mathrm{ml} \mathrm{min}^{-1}$ and the mercury vapor quantified by AFS. Concentrations of $\mathrm{HgR}_{\mathrm{D}}$ were determined using $\mathrm{SnCl}_{2}$ reduction: one aliquot $(100-200 \mathrm{ml})$ of filtered water was taken to a Teflon ${ }^{\circledR}$ bubbler, and $0.1 \mathrm{ml}$ of an acidic $\mathrm{SnCl}_{2}$ solution $\left(50 \% \mathrm{SnCl}_{2} \mathrm{w} / \mathrm{v}, 15 \% \mathrm{HCl} \mathrm{v} / \mathrm{v}\right)$ was added. The sample was then sparged for 9 minutes with $\mathrm{Hg}$-free argon (Ar passed through a gold-coated sand trap), and the reduced species were amalgamated onto a gold-coated sand trap. The trap was then heated, and the mercury vapor produced was measured by AFS detection. Total dissolved mercury concentrations were determined similarly, but after mercury compounds were decomposed by bromine oxidation according to Bloom and Crecelius (1983). Dissolved MMHg was determined after hydride formation and cryogenic chromatographic separation according to Tseng et al. (1998), using AFS for detection. The preweighted Millipore ${ }^{\circledR}$ LCR membranes $(0.45 \mu \mathrm{m})$ used for filtration were rinsed and dried $\left(50^{\circ} \mathrm{C}, 12 \mathrm{~h}\right)$ and reweighed for the determination of suspended particulate matter (SPM) concentrations. They were digested with concentrated $\mathrm{HCl}^{\prime} \mathrm{HNO}_{3}(1 / 9, \mathrm{v} / \mathrm{v})$ in Teflon ${ }^{\circledR}\left(\mathrm{PFA}, \mathrm{Savillex}^{\circledR}\right)$ reactors $\left(90^{\circ} \mathrm{C} ; 3 \mathrm{~h}\right)$ before determining the $\mathrm{HgT}_{\mathrm{P}}$ concentrations according to the same technique as for $\mathrm{HgR}_{\mathrm{D}}$. Soil samples were analyzed for $\mathrm{HgT}$ in the same manner after freeze-drying. The detailed protocols are described elsewhere (Quémerais and Cossa, 1995).

After initial removal of epibiota and freeze-drying, each mussel was shucked from their shell. Biometric measurements were performed on individual mussels: shell length, weight and soft tissue dry weight. The dried soft tissues were ground and individually analyzed using a mercury solid sample analyzer (AMA-254, Altec $($ ) ) according to Cossa et al. (2002a). Monthly mean mercury concentrations were determined using around 30 measurements obtained from individual mussels.

Detection limits, defined as 3.3 times the standard deviation of the blanks were $40 \mathrm{pg} \mathrm{l}^{-1} \mathrm{for}_{\mathrm{HgR}_{\mathrm{D}}, 80}$ $\mathrm{pg} \mathrm{I}^{-1}$ for $\mathrm{HgT}_{\mathrm{D}}, 8 \mathrm{pg}^{-1}$ for $\mathrm{MMHg}, 16 \mathrm{pg} \mathrm{I}^{-1}$ for $\mathrm{DGM}$ and $5 \mathrm{ng} \mathrm{g}^{-1}$ for $\mathrm{HgT}_{\mathrm{P}}$ and total mercury in mussels. Analytical reproductibilities varied from 5 to $10 \%$, except for the MMHg determination which varied from 10 to $20 \%$. The accuracy of the methods was checked using the available reference materials: MESS-2 from the National Research Council of Canada for particles and IAEA-142 from the International Atomic Energy Agency for mussels.

Salinity was determined from conductivity measurements using a CTD probe (Portasal ${ }^{\circledR}$, Guideline). Particulate organic carbon (POC), nitrogen (PON), hydrogen and oxygen concentrations were measured according to Hedges and Stern (1984) with a CHNO analyzer (Carlo Erba, 1106 model) after filtration of the water samples through glass fiber filters (Whatman ${ }^{\circledR} \mathrm{GF} / \mathrm{F}$ ). Water filtered through GF/F filters was used for the determination of dissolved organic carbon, according to Sempéré and 
Cauwet (1993) using a TOC 5000 (Shimadzu) analyzer. These analyses were made on water aliquots split from the samples used for mercury speciation.

\subsection{A corrective model for mercury in mussels}

Seasonal variations of mercury in the soft tissue of mussels $\left(\mathrm{Hg}_{\text {mussel }}\right)$ involving at least a two-fold amplitude have been reported for mercury in Mussel Watch programs (e.g., Cossa et al., 1980; Cossa and Rondeau, 1985; Claisse, 1989), with low concentrations in summer and high concentrations in winter. All these studies concluded that the seasonal pattern results from temporal changes in mussel metabolism. The increase of soft tissue weight during summer dilutes metal levels during this period. To account for the effects of this physiological change and improve the reliability of mussels as quantitative biological indicators, Fisher (1988) proposed a means of correcting metal concentration values in mollusk soft tissues. A "condition index" $(\mathrm{Cl})$, defined as the ratio of soft tissue dry weight to shell weight, is indicative of seasonal changes in mussel growth. The temporal distribution of the monthly Cls has been calculated for mussels from Yport and Etretat, they were related to $\mathrm{Hg}_{\text {mussel. }}(\mathrm{r}=$ - 0.81, $p<0.005$ ); high Cls lead to low $\mathrm{Hg}_{\text {mussel }}$ concentrations by a "weight dilution" effect. The following equation can be used to correct mercury concentrations measured in mussels $\left(\mathrm{Hg}_{\text {mussel }}\right)$ to account for intersect biotic influence:

$$
\mathrm{Hg}_{\text {corr }}=\mathrm{a}\left(\mathrm{Cl}_{\text {meas }}-\mathrm{Cl}_{\text {ref }}\right)+\mathrm{Hg}_{\text {mussel }}+b
$$

where $\mathrm{Hg}_{\text {corr }}$ is the corrected mercury concentration in soft tissue, a the function slope of the $\mathrm{Hg}_{\text {mussel }}$ vs $\mathrm{Cl}$ linear relationship, $\mathrm{Cl}_{\text {meas }}$ the measured condition factor, $\mathrm{Cl}_{\text {ref }}$ a chosen "reference" $\mathrm{Cl}$ (arbitrarily determined as the intercept of the $\mathrm{Hg}_{\text {mussel }}$ vs $\mathrm{Cl}$ relationship, i.e. 0.339), and $b$ an arbitrary constant value (0.4) to avoid $\mathrm{Hg}_{\text {corr }}$ negative values.

\section{Results and discussion}

\subsection{Hydrosedimentary and chemical characteristics}

Both karstic freshwater sources exhibited similar $\mathrm{pH}$ and DOC, but SPM and POC were higher for Yport compared to Etretat (Table 1). These differences are consistent with the two different rainwater pathways through the karstic structure (supported by tritium analysis according to Conrad and Essevre-Delepou, 1978) and suggest (i) slow percolation through the superficial layers and unsaturated chalk, with a resulting low SPM and POC (Etretat), and (ii) fast flow through the karst and rapid arrival at the near-shore, accounting for high SPM and POC at the Yport spring (Lechevalier, 1998) as illustrated in figure 3. The high SPM and POC values at Yport have been attributed to the increased erosion of the soil as a result of current farming practices (Vandewiele, 1999). In addition to the groundwater emergences, direct surface run-off bringing large quantities of SPM to the shore area via cliff waterfalls during heavy rain events, was observed at Etretat during the April 2000 sampling period (see insert in figure 4).

In both the mixing zones between fresh and seawater at Yport and Etretat, SPM, POC and DOC concentrations were higher and more variable than those found in the groundwater springs (Table 1). The insert in figure 4 illustrates the SPM distribution throughout the mixing zone: the concentrations tended to be higher within the 10-30 salinity range, then, for higher salinity, reached the values found in the adjacent marine coastal waters $\left(<5 \mathrm{mg} \mathrm{I}^{-1}\right.$; Coquery et al., 1997). POC covaried positively with SPM $(r=0.89 P<0.05)$ and with DOC $(r=0.86, P<0.05)$. These distribution features suggest that most particles, apart from heavy rain periods, are organic and likely of marine origin (since groundwater particles present low POC, Table 1), including the adjacent plume of the Seine estuary.

\subsection{Mercury in the groundwater seepages}

The total mercury concentrations $\left(\mathrm{HgT}_{\mathrm{D}+\mathrm{P}}\right)$, expressed per volume of freshwater, were similar regardless of the emergence site considered (Table 2). Since $\mathrm{HgT}_{\mathrm{D}+\mathrm{P}}$ includes both dissolved and particulate phases, this concentration is related to SPM concentrations $(r=0.81 ; p<0.05)$ and, consequently, the proportion of mercury borne by underground particles showed a higher mean value for Yport $(68 \pm 13 \%)$ than for Etretat $(44 \pm 10 \%)$. The $\mathrm{HgT}_{\mathrm{D}}(<0.45 \mu \mathrm{m})$ concentrations were twice as high at Etretat when compared to Yport emergence (Table 2). The $\mathrm{HgT}_{\mathrm{p}}$ concentrations, expressed 
per mass of particle, did not differ significantly between the two emergences and decreased with increasing SPM in both systems (Yport: $r=-0.82, p<0.005$; Etretat: $r=-0.75, p<0.005$ ). These relationships suggest that mercury rich particles from the emergences were diluted by those poorer in mercury from the surface runoff during high turbidity events (Fig. 6). The high $\mathrm{HgT}_{\mathrm{P}}$ concentrations found in the POC rich SPM from Yport (up to $0.32 \mathrm{ng} \mathrm{mg}^{-1}$, Table 1), and the low $\mathrm{HgT}_{\mathrm{P}}$ concentrations found in the samples of clay soil taken from the top of the cliff (Fig. 3) (mean: $0.051 \pm 0.012 \mathrm{ng} \mathrm{mg}^{-1}$, $\mathrm{n}=10$ ) support this hypothesis. Mercury speciation in the groundwater discharges was characterized by relatively high $\mathrm{HgR}_{\mathrm{D}}$ concentrations, high $\mathrm{HgR}_{\mathrm{D}} / \mathrm{HgT}_{\mathrm{D}}$ ratios (Table 2) and the undetectable levels of DGM and $\mathrm{MMHg}_{\mathrm{D}}\left(<16\right.$ and $<8 \mathrm{pg} \mathrm{I}^{-1}$ respectively) in all the samples analyzed. The distributions of $\mathrm{HgR}_{\mathrm{D}}$ concentrations displayed the same features as $\mathrm{HgT}_{\mathrm{D}}$ : higher values at Etretat than Yport (Table 2). The average $\mathrm{HgR}_{\mathrm{D}} / \mathrm{HgT}_{\mathrm{D}}$ ratios $(73 \pm 19 \%$ and $55 \pm 17 \%$ for Etretat and Yport respectively) were higher than those found in the adjacent Seine river waters (30.2 $\pm 6.5 \%$, Cossa et al., 2002a). This characteristic with low $\mathrm{MMHg}$ concentrations, corresponds rather to the typical range of rainwater than to that of river waters (e.g., Mason et al., 1997; Laurier et al., 2003a).

In addition to the Seine aquifer, precipitation is also a substantial local source of water for the karstic system (de la Querrière, 1999), especially during high precipitation periods. Total dissolved mercury concentrations measured during the three rain events sampled, ranged from 5 to $15 \mathrm{ng} \mathrm{l}^{-1}$. These high concentrations are common for rainwater (e.g., Mason et al., 1997), and within the range found during an 8-month period at Créteil, an eastern suburb of Paris in the Seine basin $\left(3.8-48.8 \mathrm{ng} \mathrm{l}^{-1}\right)$ (Cossa et al., 2002b). The intense divalent mercury reduction in the surface waters of the Seine Bay, which injects the equivalent of $20 \%$ of the mercury inputs from the Seine River as elemental mercury into the atmosphere (Cossa et al., 2002b), is a source of mercury enrichment in the precipitation which feeds the karstic system. It is generally accepted that elemental mercury is quickly re-oxidized in the marine atmosphere (e.g., Laurier et al., 2003b) and that rain borne mercury is scavenged by sorption onto soil particles during the water transit through the soil. Field data suggest generally that $\mathrm{HgT}_{\mathrm{D}}$ concentrations are higher in runoff when compared to ground water (e.g., Quémerais et al., 1999). In a karstic system the water transit is fast and the mercury partitioning and transport appear to be different from those in other soils and subsoils. As noted above, two water pathways exist in the karst of the study area (Fig. 3): pathway A (Etretat), involving slow transit with low SPM (with low POC) and high $\mathrm{Hg}_{\mathrm{D}}$, and pathway B (Yport) characterized by fast percolation through the karst, with high SPM (with high POC) and low $\mathrm{HgT}_{\mathrm{D}}$. The water transit through the faults of the carbonate rock, in the A system, does not seem to favor $\mathrm{Hg}$ adsorption onto particles. The presence of higher organic carbon in the SPM (Table 1) as observed in the B system appears to be a more efficient scavenging support.

\subsection{Mercury in freshwater-seawater mixing}

Due to the higher SPM load of near-shore seawater (Fig 4), $\mathrm{HgT}_{\mathrm{D}+\mathrm{P}}$ concentrations in the mixing zones (salinity $>1$ ) displayed a higher average value than those in freshwater sources (salinity $<1$, Table 2). The differences in $\mathrm{HgT}_{\mathrm{D}}$ concentrations between the two karstic emergences were quickly damped by the dilution by coastal waters from the English Channel and Seine estuary plume (Table 2, Fig. 5a). In order to describe the behavior of $\operatorname{HgT}_{\mathrm{D}}(<0.45 \mu \mathrm{m})$ species during mixing, we calculated the difference between the monthly $\mathrm{Hg}_{\mathrm{D}}$ concentrations measured and the theoretical values derived from the conservative mixing between the fresh water and marine end-members for the salinity considered (assuming salt conservation) (Fig. 5b). The observed differences suggest an addition of $\mathrm{Hg}_{\mathrm{D}}$ for salinity $>1$. This behavior is the inverse of the removal of $\mathrm{HgT}_{\mathrm{D}}$ in the adjacent Seine estuary (Fig 5b), where a high turbidity zone (HTZ) is present (Laurier et al., 2003a). These contrasting situations are also apparent from the comparison of $\mathrm{HgT}_{\mathrm{D}}$ concentration levels in the mixing zones. They averaged $0.73 \pm 0.21 \mathrm{ng} \mathrm{l}^{-1}$ in the Caux region compared to the Seine estuary, averaging $0.32 \pm$ $0.13 \mathrm{ng} \mathrm{I}^{-1}$ for the same salinity range (salinity 1-32) (Laurier et al., 2003a). The whole near-shore mixing zone of the groundwater seepages of the Caux region (salinity 1-32) appears to be enriched with dissolved mercury, as compared to adjacent coastal seawater (salinity $>32$ ). This could result from the partial desorption and/or solubilization from the particles in the near shore area consistent with the $\mathrm{HgT}_{\mathrm{p}}$ decrease when salinity increases (Fig. 6). Furthermore, the $\mathrm{HgT}_{\mathrm{p}}$ concentration distribution in the mixing zone tended to show a decrease with increasing SPM (Fig. 6), which contrasts strongly with the inverse observation made in the HTZ of the Seine estuary, where $\mathrm{HgT}_{\mathrm{P}}$ concentration increases with increasing SPM (Laurier et al., 2003a). The HTZ of the Seine estuary acts as a dissolved mercury removal system while, on the contrary, the mixing zone of the Caux region receives the dissolved mercury inputs from the groundwater seepage with an apparent $\mathrm{Hg}$ transfer from the particulate phase. In order to explore the mercury partition between dissolved and particulate changes within the estuarine mixing zones, we calculated the partition or distribution 
coefficient, $\mathrm{Kd}$, defined as the ratio between $\mathrm{HgT}_{\mathrm{P}}$ and $\mathrm{Hg}_{\mathrm{D}}$. The highest values for $\mathrm{Kd}$ are associated with low salinity and low turbidity (Fig. 7), and tend to decrease exponentially when these parameters increase. However, the only relationships statistically significant were between logKd and SPM concentrations (Yport: $r=-0.81, p<0.005$; Etretat: $r=-0.72, p<0.005$ ). In addition to the exponential $\mathrm{HgT}_{\mathrm{P}}$ decrease with SPM increase $(\mathrm{r}=-0.79, p<0.001)$, these relationships might reflect a "colloidal effect". According to Benoit et al. (1994) and Benoit and Roza (1999), this effect results in a proportional increase in the amount of colloidal material when SPM concentration increases. Since the colloidal fraction is in practice measured within the "so-called dissolved" fraction (i.e., the $<0.45 \mu \mathrm{m}$ ), this "dissolved" fraction might be overestimated.

In addition to the total mercury partition, we also explored the mercury speciation in the mixing areas. The distributions of reactive dissolved mercury $\left(\mathrm{HgR}_{\mathrm{D}}\right)$ concentrations displayed comparable concentrations within both mixing zones (Table 2). From figure 8 , it can be seen that $\mathrm{HgR}_{\mathrm{D}}$ concentrations from both mixing zones of the Pays de Caux were more variable (mean: $0.39 \pm 0.13 \mathrm{ng}$ $\mathrm{I}^{-1}$ ) and twice as high as those measured in the adjacent Seine estuary (mean: $0.14 \pm 0.05 \mathrm{ng} \mathrm{I}^{-1}$ ) (Laurier et al., 2003a). This suggests that the dissolved mercury in these environments was associated with weaker ligands than in the Seine estuary. For the highest salinities $(>32), H_{g} R_{D}$ values corresponded to those found for adjacent coastal seawater (Fig. 8). The ratios $\mathrm{HgR}_{\mathrm{D}} / \mathrm{HgT}_{\mathrm{D}}$ found in the mixing zones ranged from 0.27 to 0.69 (Table 2) and increased seaward, which is the common pattern for coastal environments (Cossa et al., 1996; Kwokal and Branica, 2000; Rolfhus and Fitzgerald, 2001). The low DOC concentrations (means: $0.9 \pm 0.4$ and $0.7 \pm 0.3 \mathrm{ng} \mathrm{l}^{-1}$, for Etretat and Yport respectively, Table 1) compared to the concentrations in the Seine estuary HTZ waters (mean: $2.3 \pm 0.4 \mathrm{ng} \mathrm{l}^{-1}$ according to Laurier et al., 2003a) and/or the nature of the various organic ligands may account for the higher $\mathrm{HgR}_{\mathrm{D}} / \mathrm{HgT}_{\mathrm{D}}$ ratios found for the two sites of the Pays de Caux mixing zones compared to the Seine estuary. This pattern is consistent with the organic matter vs mercury speciation models found for other coastal environments (e.g., Lamborg, 2003; Stordal et al., 1996).

Summary statistics for DGM and $\mathrm{MMHg}_{\mathrm{D}}$ are shown in table 3 for surface samples collected in February 2000 along the Pays de Caux coast line for salinities ranging from 32.2 to 32.8 , with the equivalent results for two adjacent environments: the Seine bay and estuary. The mean concentrations for DGM was $50.7 \mathrm{pg} \mathrm{I}^{-1}$ compared to 18.1 and $30.3 \mathrm{pg} \mathrm{I}^{-1}$ for the adjacent Seine estuary and bay. This represents 2.4 to $7.8 \%$ of the $\mathrm{HgT}_{\mathrm{D}}$ in the Caux region compared to 5.5 to 11.6 $\%$ in the Seine estuary. The mean $\mathrm{MMHg}_{\mathrm{D}}$ concentrations (mean: $12.5 \mathrm{pg}^{-1}$ ) did not differ greatly from the levels measured in the Seine estuary and in the bay: 16.5 and $11.7 \mathrm{pg} \mathrm{I}^{-1}$ respectively (Table 3), but were significantly higher than in the seepage waters. MMHg to $\mathrm{HgT}$ ratios in the dissolved phase did not differ among these three environments.

In summary, the most striking characteristic of the mercury speciation in these groundwater estuaries is the high dissolved mercury concentrations and the high $\mathrm{HgR}_{\mathrm{D}} / \mathrm{HgT}_{\mathrm{D}}$ ratios. The MMHg levels do not differ from the HTZ of the man-perturbed Seine estuary. The biogeochemical difference between the subterranean estuary studied here and a turbid estuary lies in the "filter effect" of the organically rich HTZ on the dissolved mercury transfer to coastal waters (Laurier et al., 2003a). In addition, the high biological productivity in the Seine estuary could favor the mercury scavenging processes. In the low turbidity subterranean estuaries of the Pays de Caux, less mercury seems to be scavenged, resulting in proportionally more dissolved mercury available for biological uptake, since the pool of dissolved reactive mercury is known to be, in addition to $\mathrm{MMHg}$, bioavailable for the marine food chain (Mason et al., 1996a and b).

\subsection{Mercury in mussels}

Summary statistics for mercury concentrations ( $\left.\mathrm{Hg}_{\text {mussel }}\right)$ in soft tissues of the mussels (Mytilus edulis) sampled monthly at Yport and Etretat between March 2000 and February 2001 are shown in table 4. Since the $\mathrm{Hg}_{\text {mussel }}$ concentrations were highly variable from month to month, a corrective model was applied to the $\mathrm{Hg}_{\text {mussel }}$ data to minimize the effect of the physiological changes of the mollusks during the various seasons (see section 2.4.). Thus, the "normalized" $\mathrm{Hg}_{\text {mussel }}$ (Table 4 and Fig. 9) are assumed to reflect the mercury bioavailability in the surrounding environment of the mussels eliminating the effect of seasonal biological cycles within the mussels. From figure 9, the most striking feature was the significantly $(p<0.01)$ higher concentrations of $\mathrm{Hg}_{\text {mussel }}$ from the Pays de Caux compared to the mussels from the adjacent Seine estuary during the sampling period. Similar observations were made before 2000 and after 2001 within the framework of the French Mussel Watch (Fig. 2). It is interesting to note that this difference in mercury concentrations in the mussels matches with the difference in mercury concentrations in their surrounding waters (Fig. 5a and 8). 
In addition to dissolved mercury in water, the particulate phase appears to be a potential source for mussels (e.g. Gagnon and Fisher, 1997). This possibility was checked by subjecting suspended particles collected in the mixing zones to weak acidification to $\mathrm{pH} \sim 4$ in order to mimic the condition of the digestive tract of a mussel (e.g., Wang et al., 1995). The solubilized fraction from estuarine particles (Table 5) was found to correspond to 5 to $10 \%$ of the particulate mercury initially present in mixing zone particles. However, when the treatment was applied to clay and chalk particles, mercury initially present in the dissolved phase was sorbed (Table 6). Thus, it can be concluded that the potentially bioavailable mercury for mussels comes from mixing zone water and particles.

\section{Summary}

1. Three freshwater sources reach the coast of the Caux region (English Channel, France): two karstic groundwater sources with different hydrogeological profiles and direct surface run-off. The groundwater sources consist of (i) a slow percolation through superficial layers and unsaturated chalk, resulting in a low SPM, followed by fast flow through the karst and (ii) a rapid arrival of waters at the near-shore, resulting in high SPM and POC values at the spring. Runoff, especially during heavy rain events, carries large quantities of SPM to the shore area via cliff waterfalls. The partitioning and speciation results indicate that mercury distribution in groundwater sources is strongly affected by a common mercury-rich source (rain) and the dynamics of the particle load. A short water pathway through karstic fractures (Yport springs) is associated with high turbidity and thus with a scavenging of dissolved mercury that promotes mercury transport by particles. Longer pathways in the karst (Etretat springs) promote particle sedimentation and the transport of mercury in the dissolved phase. Storm events bring particulate mercury pulses to the coastline. When mercury is carried by the karst system, mainly in the dissolved phase, $\mathrm{HgR}_{\mathrm{D}}$ and $\mathrm{HgT}_{\mathrm{D}}$ concentrations and the $\mathrm{HgR}_{\mathrm{D}} / \mathrm{HgT}_{\mathrm{D}}$ ratios can be twice as high as in the adjacent Seine River.

2. Despite partitioning differences at the freshwater sources, mercury distributions (concentration and partitioning) were similar in the two groundwater estuaries studied. This suggests that the mixing dynamics of this near-shore coastal line (tidal amplitude beyond $4 \mathrm{~m}$ ), is very effective and that dissolved-particulate mercury exchanges occur early, with mixing of groundwater and seawater. Total groundwater discharge represents around one hundred cubic meters per second, which appears sufficient to make the Caux region near-shore area a chemically distinct and particular estuarine environment. In fact, $\mathrm{HgR}_{\mathrm{D}}$ and $\mathrm{HgT}_{\mathrm{D}}$ are higher in the Caux region than in the Seine River mixing zone, while speciation, as indicated by the DGM and MMHg, is comparable. $\mathrm{HTZ}$ of the Seine estuary acts as a dissolved mercury removal system while, on the contrary, the mixing zone of the Caux region receive the dissolved mercury inputs from the groundwater seepage with an apparent $\mathrm{Hg}$ transfer from the particulate phase. The low turbidity of the groundwater estuaries of the Caux region prevents significant mercury scavenging.

3. Consistently, the mercury concentrations in the soft tissue of the mussel (M. edulis), used as a sentinel organism at from Etretat and Yport, are at least twice as high as the concentrations in the mussels from the adjacent Seine estuary. The similar patterns of mercury concentration observed in mussels and water suggest that the waters of the Pays de Caux groundwater estuaries are a source of bioavailable mercury for mussels. Laboratory experiments suggest that the potentially bioavailable mercury for mussels comes from mixing zone water and particles.

Acknowledgments. The authors are grateful to A. Vandewiele, B. Burnett, B. Sundby and C. Lechevalier for helpful discussions about groundwater dynamics and to J. Bretaudeau and S. Mercier for assistance in sampling operations. This study was supported by the "Agence de l'eau SeineNormandie, délégation d'Honfleur," and the Seine-Aval Research Program. 


\section{References}

BENOIT, G., S. D. OKTAY-MARSHALL, A. CANTU, E. M. HOOD, C.H. COLEMAN, M. O. CORAPCIOGLU, AND P. H. SANTSCHI. 1994. Partitioning of $\mathrm{Cu}, \mathrm{Pb}, \mathrm{Ag}, \mathrm{Zn}, \mathrm{Fe}, \mathrm{Al}$, and $\mathrm{Mn}$ between filter retained particles, colloids and solution in six Texas estuaries. Mar. Chem. 45: 307-336.

BENOIT, G., AND ROZA, T. F. 1999. The influence of size distribution on the particle concentration effect and trace metal partitioning in rivers. Geochim. Cosmochim. Acta, 63: 113-127.

BEUCHER, C., F. J. G. LAURIER AND D. COSSA. Submitted. Gaseous mercury formation in the Seine estuary and bay, France.

BLOOM, N., AND CRECELIUS. 1983. Determination of mercury in seawater at sub-nanogram per liter levels. Mar. Chem; 14: 49-59.

BLOOM, N., AND W.F. FITZGERALD. 1988. Determination of volatile mercury species at the picogram level by low temperature gas chromatography with cold-vapour atomic fluorescence detection. Anal. Chim. Acta. 208: 151-161.

BOUDREAU, P. R.,AND P. J. F. GEEDERS. 1996. LOICZ Data and Information System Plan. LOICZ Reports \& Studies No. 6. Texel, The Netherlands., LOICZ: ii + 62.

BURNETT, B., AND J. TURNER. 2001. LOICZ group investigates groundwater discharge in Australia. LOICZ Newsletter No 18: 1-4.

CABLE, J., G. BUGNA, W. BURNETT, AND J. CHANTON. 1996. Application of ${ }^{222} \mathrm{Ra}$ and $\mathrm{CH} 4$ for assessment of groundwater discharge to the coastal ocean. Limnol. Oceanog. 41: 1347-1353.

CHARETTE, M.A., SHOLKOVITZ, E.R. and HANSEL, C.M. 2005. Trace element cycling in a subterranean estuary: Part 1. Geochemistry of the permeable sediments. Geochim. Cosmochim. Acta, 69 : 2095-2109.

CHARETTE, M.A. and SHOLKOVITZ, E.R 2006. Trace element cycling in a subterranean estuary: Part 2. Geochemistry of the pore water. Geochim. Cosmochim. Acta, $70: 811-826$.

CLAISSE, D. 1989. Chemical contamination of French coasts, the result of a ten years mussel watch. Mar. Pollut. Bull. 20: 523-528.

CLAISSE, D., D. COSSA, J. BRETAUDEAU-SANJUAN, G. TOUCHARD AND B. BOMBLED. 2001. Methylmercury in Mollusks along the French coast. Mar. Pollut. Bull. 42: 329-332.

COQUERY, M., D. COSSA, J. BRETAUDEAU-SANJUAN. 1997. Speciation and sorption of mercury in two macro-tidal estuaries. Mar. Chem. 58: 213-227.

CONRAD, D., AND A. ESSEVRE-DELEPOU. 1978. The relationships between the aquifer of the overexploited chalk and the superficial waters in the shield of the Seine (Seine-Maritime): Tritium tracing of the contribution of the river. BRGM Report 137:147, Orleans, France.

CORBETT, D. R., J. CHANTON, W. BURNETT, K. DILLON, AND C. RUTKOWSKI. 1999. Patterns of groundwater discharge into Florida Bay. Limnol. Oceanogr. 44: 1045-1055.

CORBETT, D. R., L. KUMP, K. DILLON, W. BURNETT, AND J. CHANTON. 2000. Fate of wastewater-borne nutrients under low discharge conditions in the subsurface of the Florida Keys. Mar. Chem. 69: 99-115.

COSSA D., AND J.-G. RONDEAU. 1985. Seasonal, geographical and size-induced variability in mercury content of Mytilus edulis in an estuarine environment: a re-assessment of mercury pollution level in the estuary and gulf of St Laurent. Mar. Biol. 88: 43-49.

COSSA, D, M. COQUERY, K. NAKHLE AND D. CLAISSE. 2002a. Dosage du mercure total et du monométhylmercure dans les organismes et les sédiments marins. Méthodes d'analyse en milieu marin. Co-édition Ifremer et Ministère de l'Ecologie et du Développement Durable. 26 pp. ISBN 2-84433-105-X

COSSA D., F.J. G. LAURIER AND A. FICHT. 2002b. Mercury Contamination in the Seine Estuary, France: An Overview. Chap. 20. P.298-320. In: Biogeochemistry of Environmentally important Elements", Y. Cai et O.C. Braids eds. ACS Symposium Series 835, American Chemical Society, Washington, DC, $436 \mathrm{pp}$. 
COSSA, D., AND A. FICHT. 1999. La dynamique du mercure. Fascicule programme scientifique Seine-Aval. 11. 25p.

COSSA, D., E. BOURGET, D. POULIOT, J. PIUZE, AND J.P. CHANUT. 1980. Geographical and seasonal variations in the relationship between trace metal content and body weight in Mytilus edulis. Mar. Biol. 58: 7-14.

COSSA, D., M. COQUERY, C. GOBEIL, AND J.-M. MARTIN. 1996. Mercury flux at the ocean margins. In: Baeyens, W. Ebinghaus, R. Vasiliev, O. (Eds.). Global and Regional Mercury Cycles: Sources, Fluxes and Mass Balances. Kluwer, Dordrecht, pp. 229-247.

DE LA QUERRIERE, PH. 1999. L'aquifère crayeux en Haute Normandie. Rapport du BRGM. No 83 SGN 030 HNO. $10 \mathrm{p}$.

FISHER, H. 1988. Mytilus edulis as a quantitative indicator of dissolved cadmium. Final study and synthesis. Mar. Ecol. Prog. Ser. 48: 163-174.

GAGNON, C., and N. S. FISHER. 1997. Bioavailability of sediment bound methylmercury and inorganic mercury to a marine bivalve. Environ. Sci. Technol. 31: 993-998.

GORDON, J. D. C., P. R. BOUDREAU, K. H. MANN, J.-E. ONG, W. L. SILVERT, S. V. SMITH, G. WATTAYAKORN, F. WULFF AND T. YANAGI. 1996. LOICZ Biogeochemical Modelling Guidelines. LOICZ Reports \& Studies No 5, 1-96.

GORDON, J., D. C., AND P. R. BOUDREAU. 1995. LOICZ Biogeochemical Modelling Guidelines. LOICZ Reports \& Studies No. 5. Texel, The Netherlands, LOICZ: vi + 96.

HAMMERSCHMIDT, C.R., AND W.F. FITZGERALD. 2004. Geochemical controls on the production and distribution of methylmercury in near shore marine sediments. Environ. Sci. Technol. 38, 1487-1495.

HEDGE, J.I., AND J.H. STERN. 1984. Carbon and nitrogen determinations of carbonate-containing solids. Limnol. Oceanogr. 29: 663-666.

JOHANNES, R. E. 1980. The ecological significance of the submarine discharge of groundwater. Mar. Ecol. Prog. Ser. 3: 365-373.

KWOKAL, Z. AND BRANICA, M. 2000. Determination of Dissolved Monomethylmercury in Saline, Estuarine and Freshwaters of Croatia. Croatia Chemica acta, 73: 97-109.

LAURIER, F., D. COSSA, J.L. GONZALEZ, E. BREVIERE AND G. SARAZIN. 2003a. Mercury transformations and exchanges in a high turbidity estuary: the role of organic matter and amorphous oxyhydroxides. Geochim. Cosmochim. Acta, in press.

LAURIER, F.J.G., R.P. MASON, L.M. WHALIN AND S. KATO. 2003b. Reactive gaseous mercury formation in the North Pacific Ocean's marine boundary layer: A potential role of halogen chemistry. JGR-Atmos. 108: D17, Art. \# 4529, doi: 10.1029/2003JD003625

LECHEVALIER, C. 1998. Conditions de circulation des Eaux de ruissellement dans les bassinsversants d'Etigue et de Vaucottes, incidences possibles sur la pollution littorale. Rapport Universitaire. Centre de Geographie Physique H. Elhaï. Paris X. Nanterre, Agence de l'Eau Seine-Normandie. 33 p.

LAMBORG, C. H. 2003. Mercury speciation and reactivity in the coastal and estuarine waters of Long Island Sound (New York). PhD dissertation. 96 pages. University of Connecticut, USA. ISBN 0-496-28793-1.

MASON, R. P., AND FITZGERALD, W.F. 1993. The distribution and biogeochemical cycling of mercury in the equatorial Pacific Ocean. Deep-Sea Res. I, 40: 1897-1924.

MASON, R. P., J. R. REINFELDER, AND F.M.M. MOREL. 1996a. Bioconcentration of mercury and methylmercury. Water Air soil Pollut. 80: 915-921.

MASON, R. P., J. R. REINFELDER, AND F.M.M. MOREL. 1996b. Uptake, toxicity and trophic transfer of mercury in coastal diatom. Env. Sci. Technol. 30: 3191-3198. 
MASON, R. P., N. M. LAWSON, AND K. A. SULLIVAN. 1997. The concentration, speciation and sources of mercury in Chesapeake Bay precipitation. Atmospheric Environment 21: 35413550 .

MICKAC, N., Z. KWOKAL, D. MARTINCIC, AND M. BRANICA. 1996. Uptake of mercury species by transplanted mussels Mytilus galloprovincialis under estuarine conditions (Krka river estuary). Sci. Total Environ. 184: 173-182.

MONTLUCON, D. and S.A. SANUDO-WIHELMY. 2001. Influence of net groundwater discharge on the chemical composition of a coastal environment/ Flanders Bay, Long Island, New York. Environ.Sci. Technol., 35: 480-486.

MOORE, W. S. 1996. Large groundwater inputs to coastal waters revealed by ${ }^{226} \mathrm{Ra}$ enrichments. Nature 380: 612-614.

OUVRY, J.F. 1992. L'évolution de la grande culture et l'érosion des terres dans le Pays de Caux. Bull. Assoc. Franç. Paris 2: 107-113.

POULET, S., D. COSSA AND J.C. MARTY. 1986. Combined analyses of the size spectra and biochemical composition of particles in the St. Lawrence estuary. Mar. Ecol. Prog. Ser. 30: 205-214

QUEMERAIS, B., AND D. COSSA. 1995. Protocoles d'échantillonnage et d'analyse du mercure dans les eaux naturelles. Environnement Canada - région du Québec, Conservation de l'environnement, Centre Saint-Laurent. Rapport scientifique et technique ST-31, 39 p.

QUEMERAIS, B., D. COSSA, B. RONDEAU, T.T. PHAM, P. GAGNON, and B. FORTIN. 1999. Sources and Fluxes of Mercury in the St. Lawrence River. Environ. Sci. Technol. 33: 840-849.

ROLFHUS, K.R. and FITZGERALD, W.F. 2001. The evasion and spatial/temporal distribution of mercury species in Long Island Sound, CT-NY. Geochim. Cosmochim. Acta, 65 : 407-418, 2001.

SEMPERE, R., AND G. CAUWET. 1993. Carbone organique dissous et colloïdal dans l'estuaire du Rhône: comparaison des techniques UV-persulfate et HTCO. C. R. Acad. Sci. Paris. 317: 5763.

SPINELLI, G.A., A.T. FISHER, C. G. WHEAT, M.D. TRYON, K. M. BROWN, and A. R. FLEGAL. 2002. Groundwater seepage into northern San Francisco Bay: Implications for dissolved metals budgets. Wat. Res. Research. 38: 10.029.

STORDAL M. C., GILL G. A., WEN L. S., and SANTCHI P. H. 1996. Mercury phase speciation in surface water of three Texas estuaries: Importance of colloidal forms. Limnol. Oceanogr. 41, 52-61.

TSENG, C. M., A. DE DIEGO, H. PINAY, D. AMOUROUX, and O. F. X. DONARD. 1998. Cryofocusing coupled to atomic absorption spectrometry for rapid and simple mercury speciation in environmental matrices. J. Anal. Atom. Spectr. 13: 755-764.

VANDEWIELE, A. 1999. Le point sur la vulnérabilité et la protection des captages d'eau potable. Mémoire D.E.S.S., Faculté d'Histoire-Géographie. Université d'Artois-Picardie. Amiens. 57 p.

WANG, W-X., FISHER, N. S. and LUOMA, S. N. 1995. Assimilation of trace elements ingested by the mussel Mytilus edulis: Effects of algal food abundance. Mar. Ecol. Prog. Ser. 129: 165-176 
Table 1. Means \pm standard deviations and (in parentheses) the number of determinations and ranges for hydrogeochemical characteristics of the various water masses studied.

\begin{tabular}{|c|c|c|c|c|c|c|}
\hline Site & Sampling area & Salinity & $\begin{array}{c}\text { SPM } \\
\left(\mathrm{mg} \mathrm{I}^{-1}\right)\end{array}$ & $\begin{array}{c}\text { POC } \\
\text { (\% SPM) }\end{array}$ & $\begin{array}{c}\mathrm{DOC} \\
\left(\mathrm{mg} . \mathrm{I}^{-1}\right)\end{array}$ & $\mathrm{pH}$ \\
\hline \multirow[b]{2}{*}{ ETRET } & Karstic freshwater & $<1$ & $\begin{array}{c}3.4 \pm 1.7(18) \\
(1.6-9.2)\end{array}$ & $0.9 \pm 0.3(9)$ & $0.3 \pm 0.1(9)$ & $7.6 \pm 0.1(10)$ \\
\hline & Mixing zone & $1-33$ & $\begin{array}{c}34.4 \pm 37.7(22) \\
\quad(1.8-151.8)\end{array}$ & $2.8 \pm 1.6(6)$ & $0.9 \pm 0.4(6)$ & $8.0 \pm 0.3(20)$ \\
\hline YPOR & Mixing zone & $1-33$ & $\begin{array}{c}30.7 \pm 19.5(18) \\
\quad(4.8-65.4)\end{array}$ & $2.9 \pm 0.9(8)$ & $0.3 \pm 0.1(7)$ & $8.0 \pm 0.4(18)$ \\
\hline
\end{tabular}


Table 2. Means \pm standard deviations and (in parentheses) number of determinations and ranges for mercury concentrations of the various water masses studied. $\log _{10} \mathrm{Kd}=\log _{10}\left(\mathrm{HgT}_{\mathrm{P}} / \mathrm{Hg} \mathrm{T}_{\mathrm{D}}, \mathrm{l} / \mathrm{kg}\right)$.

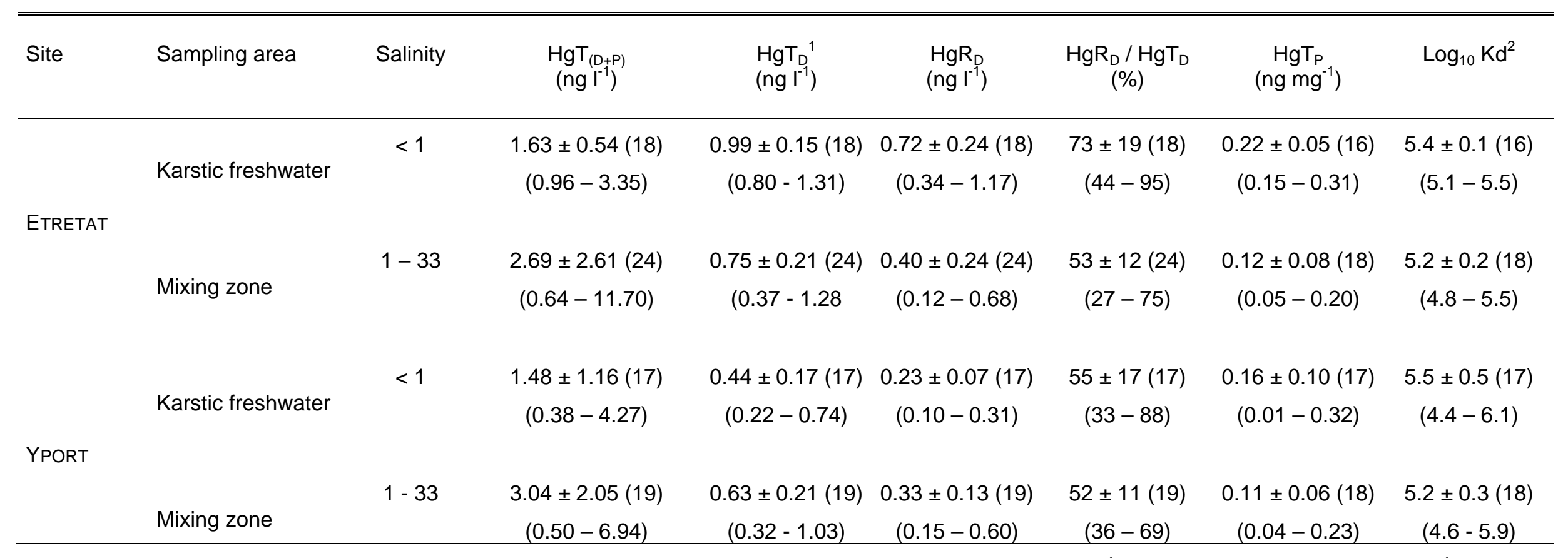

(1): intermediate values for $\mathrm{HgT}_{\mathrm{D}}$ were found in other springs from the Caux region at Veules $\left(0.67 \pm 0.10 \mathrm{ng} \mathrm{\textrm {I } ^ { - 1 }}\right)$ and $\mathrm{Vaucottes}\left(0.66 \pm 0.01 \mathrm{ng} \mathrm{I}^{-1}\right)$ sampled during a single sampling trip (Fig. 1); (2): $\mathrm{Kd}=\mathrm{Hg}_{\mathrm{P}} / \mathrm{Hg}_{\mathrm{D}}$, with logKd varying between 4.6 and 6.0 for North Atlantic estuaries according to Coquery et al. (1997). 
Table 3. Speciation measurements. Means \pm standard deviations and ranges in parentheses for the measurements made during the February 2000 cruise. DGM: dissolved gaseous mercury consists of $\mathrm{Hg}^{0}$ since dimethylmercury was insignificant; $\mathrm{MMHg}_{\mathrm{D}}$.: dissolved monomethylmerury.

\begin{tabular}{lcc}
\hline \hline Location & DGM $(\mathrm{pg} \mathrm{I})^{-1}$ & $\left.\mathrm{MMHg}_{\mathrm{D}}(\mathrm{pg} \mathrm{I})^{-1}\right)$ \\
\hline Caux Region & $50.7 \pm 19.4(8)$ & $12.5 \pm 1.5(6)$ \\
& $(36.1-86.3)$ & $(9.5-13.5)$ \\
Seine Estuary & $18.1 \pm 10.3(9)$ & $(12.5 \pm 3.5(7)$ \\
& $(2.0-32.1)$ & $11.7 \pm 5.0(5)$ \\
Seine Bay & $30.3 \pm 24.9(9)$ & $(9.6-13.9)$ \\
& $(8.0-74.2)$ & 11.7 \\
\hline
\end{tabular}


Table 4. Summary statistics of mercury concentrations $\left(\mu \mathrm{g} \mathrm{g}^{-1}, \mathrm{~d} . \mathrm{w}\right.$.) in soft tissues of mussels ( $M$. edulis). Normalized data refer to normalized values taking into account the effect of physiology on the bioaccumulation of mercury in the soft tissue of the mussel (see section 2.4.).

\begin{tabular}{lccc}
\hline \hline Site & $\mathrm{Hg}_{\text {mussel }}$ rough data & Hg & \\
\hline \multirow{2}{*}{ ETRETAT } & Mean \pm standard deviation $(\mathrm{n})$ & $0.29 \pm 0.13(134)$ & $0.41 \pm 0.08(134)$ \\
& Range & $0.10-0.62$ & $0.42 \pm 0.08(158)$ \\
YPORT & Mean \pm standard deviation $(\mathrm{n})$ & $0.32 \pm 0.13(158)$ & \\
\hline
\end{tabular}


Table 5. "Dissolved" mercury ( $\mathrm{Hg}_{\mathrm{D}}$ includes true dissolved and colloidal matter) changes in certain laboratory conditions (darkness; temperature $20^{\circ} \mathrm{C}$; salinity 25; $\mathrm{pH} 3.5-4.0$, range which mimics the acidic condition of the digestive tract of a mussel). Suspension of natural particles $\left(80 \mathrm{mg} \mathrm{l}^{-1}\right)$ were stirred for $90 \mathrm{~min}$ and then filtered $(<0.45 \mu \mathrm{m})$ to quantify $\mathrm{HgT}_{\mathrm{D}}$. Experiments were performed in $250 \mathrm{ml}$ Teflon beakers containing clay and chalk from cliffs of the Caux region and particles from the estuarine mixing zones. Number of replicates in parentheses.

\begin{tabular}{cccc}
\hline \hline \multirow{2}{*}{ Type of particle } & \multicolumn{2}{c}{$\mathrm{HgT}_{\mathrm{D}}\left(\mathrm{ng} \mathrm{l}^{-1}\right)$} & \multicolumn{2}{c}{$\begin{array}{c}\text { Percentages } \\
\text { syllubilized (+) or adsorbed (-) }\end{array}$} \\
\cline { 2 - 4 } & Without particles & With particles & +18 \\
Mixing zone & $0.96 \pm 0.07(3)$ & $1.14 \pm 0.05(3)$ & -47 \\
Clay & $1.49 \pm 0.06(3)$ & $0.79 \pm 0.03(3)$ & -19 \\
Chalk & $1.49 \pm 0.06(3)$ & $1.21 \pm 0.09(3)$ & \\
\hline
\end{tabular}




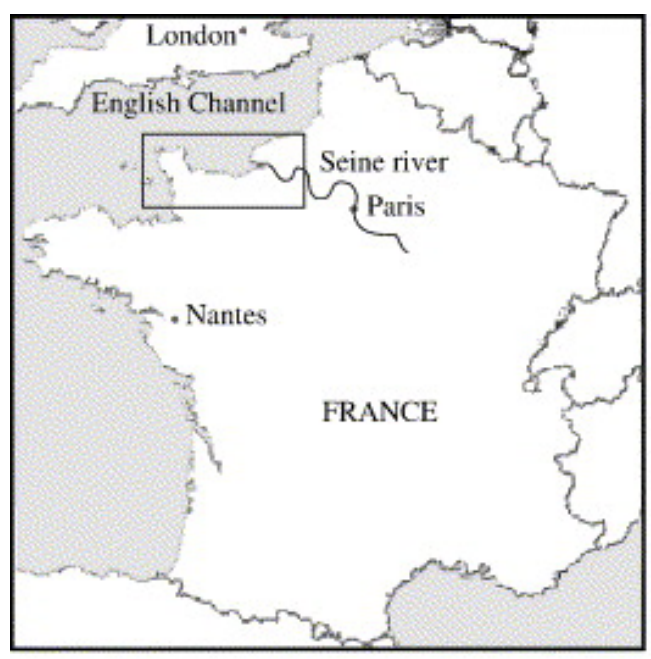

\section{Caux Region}
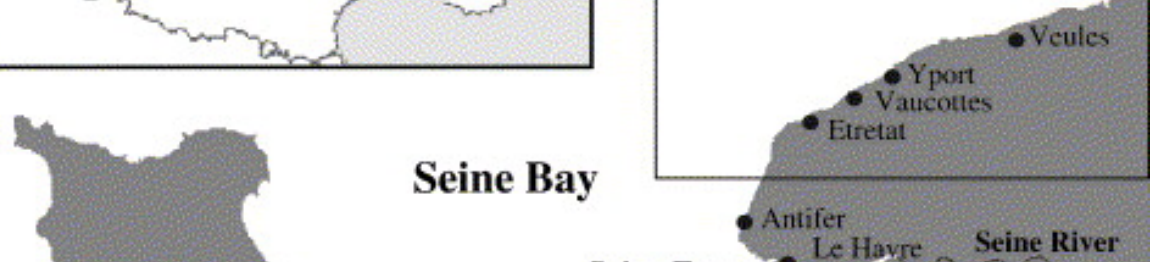

Seine Estuary - Villerville

FRANCE

Figure 1. Study area: Seine Bay, Seine estuary and the Caux region.

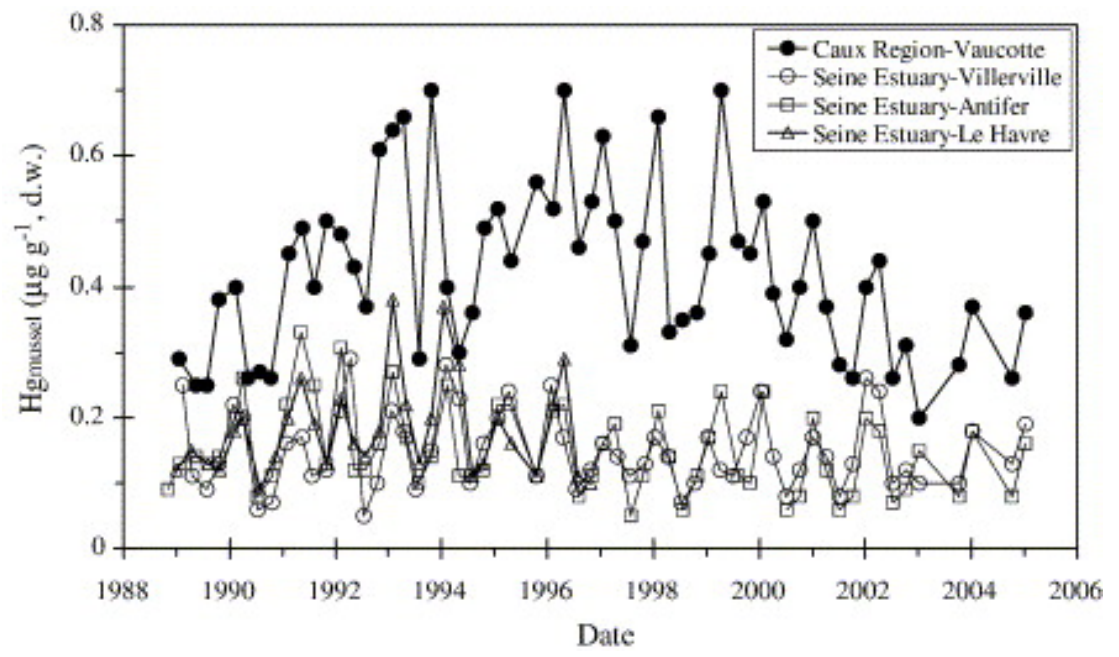

Figure 2. Temporal trend (from 1989 to 2005) in mercury concentrations ( $\mathrm{Hg}_{\text {mussel }}$ ) in the soft tissue (d.w.: dry weight) of mussels (Mytilus edulis) from the Seine estuary and the Caux region. Data from the French Mussel Watch program, RNO (http://www.ifremer.fr/envlit/surveillance/rno.htm). 
A) Slow percolation through the karst (Etretat) Karst system:

B) Fast flow through the karst (Yport)

C) Surficial runoff with storm conditions

Surficial layers (clay)

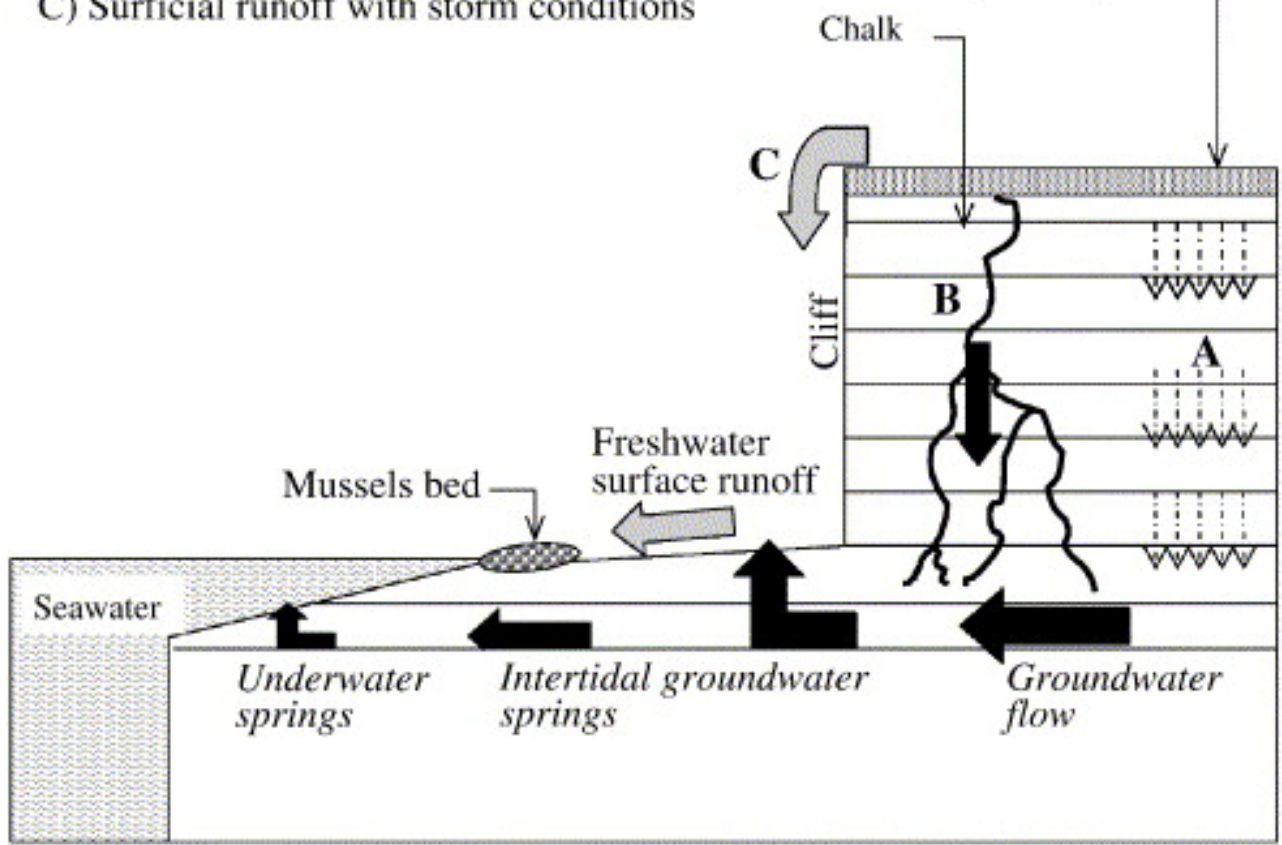

Figure 3. Schematic view in low tide conditions of the Caux region sampling sites in the French coastal zone of the English Channel, showing the different pathways of superficial and groundwater discharges. 

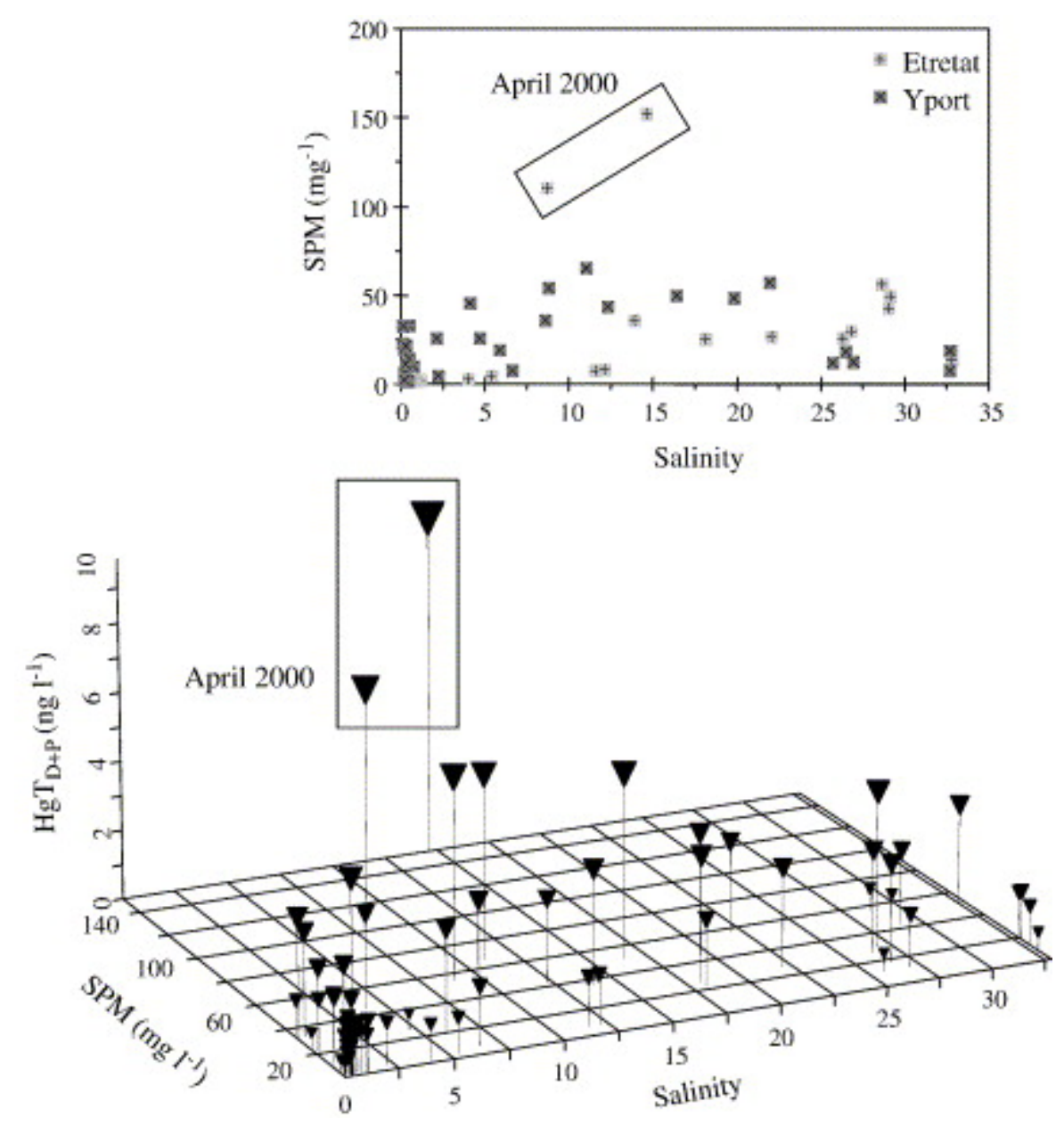

Figure 4. Total (dissolved + particulate) mercury concentrations $\left(\mathrm{HgT}_{\mathrm{D}+\mathrm{P}}\right)$ for both sampling sites in relation to salinity and suspended particulate matter (SPM). Symbol size increases as total mercury concentrations become higher. The insert indicates SPM distribution versus salinity for Yport and Etretat groundwater springs and mixing zones. The two high SPM and $\mathrm{HgT}_{\mathrm{D}+\mathrm{P}}$ values correspond to a storm period with considerable surface runoff. 

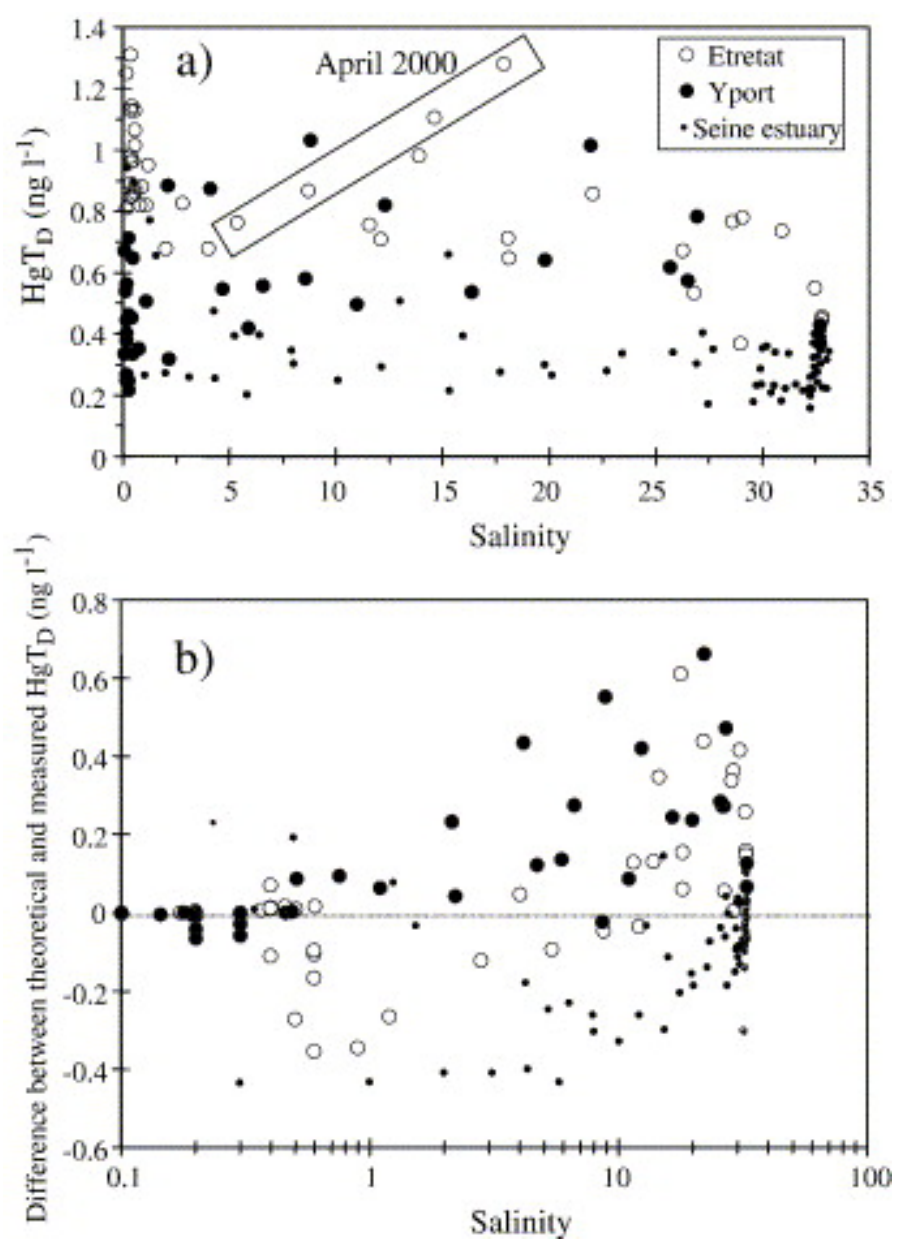

Figure 5. Total dissolved mercury $\left(\mathrm{HgT}_{\mathrm{D}}\right)$ variations with salinity. Results are expressed (a) in concentration units (the four high $\mathrm{HgT}_{\mathrm{D}}$ values correspond to a storm period with considerable surface runoff) and (b) monthly differences between the measured total dissolved mercury value and the theoretical value calculated on the basis of a conservative mixing between freshwater and marine end-members (positive values mean the addition and negative values the removal of dissolved chemical species). 


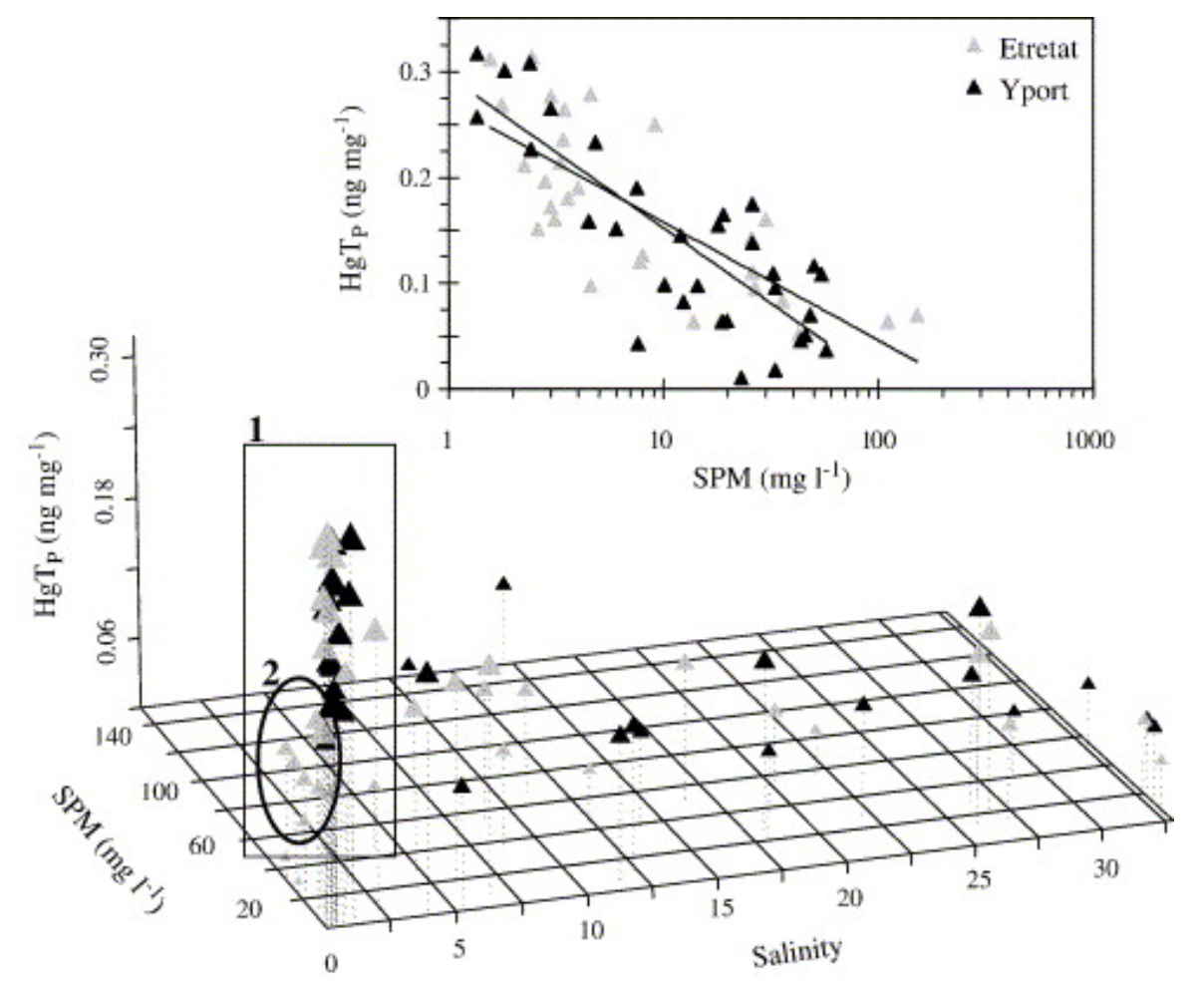

Figure 6. Total particulate mercury concentrations $\left(\mathrm{Hg}_{\mathrm{P}}\right)$ for Yport (grey) and Etretat (black) in relation to salinity and suspended particulate matter (SPM). Size symbols increase as total particulate mercury concentrations become higher. The square (1) corresponds to both groundwaters $\left(<1 \times 10^{-3}\right)$, and the circle (2) to Yport groundwater during a high turbidity event. The insert refers to the relationships between $\mathrm{HgT}_{\mathrm{P}}$ and SPM only.

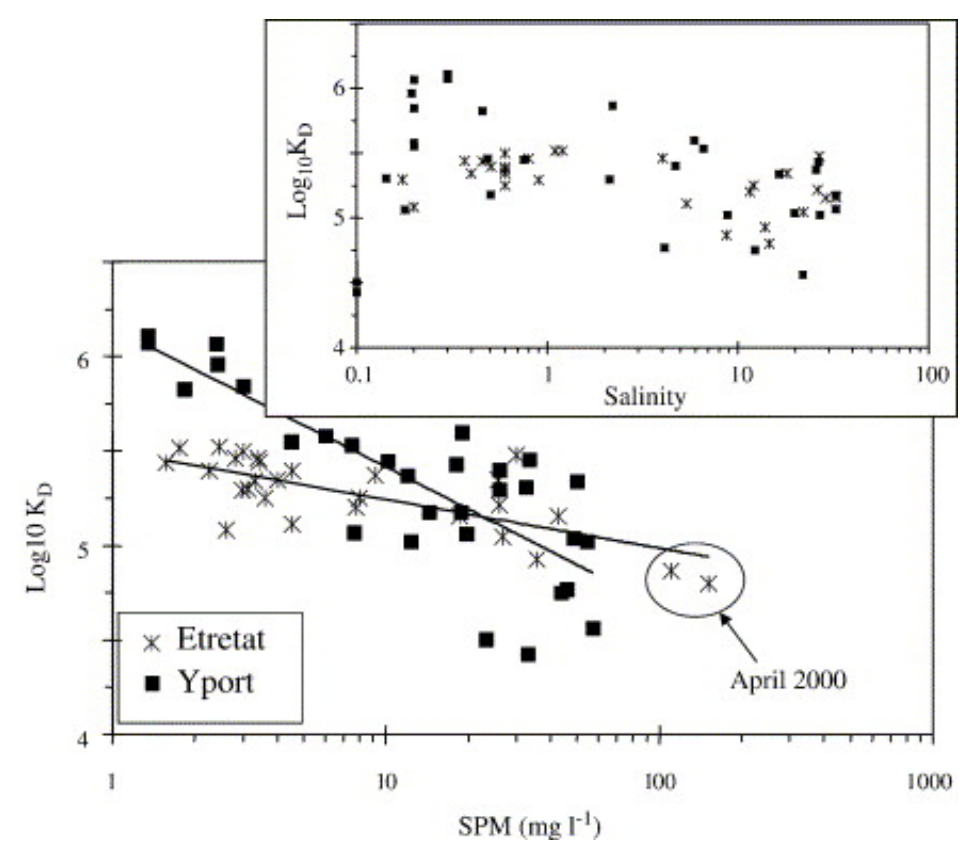

Figure 7. The coefficients of partition (Kd) expressed as the $\mathrm{HgT}_{\mathrm{P}} / \mathrm{HgT}_{\mathrm{D}}$ ratio $\left(\mathrm{l} \mathrm{kg}^{-1}\right)$ related to suspended particulate matter. The insert refers to the relationships between logKd and salinity. 


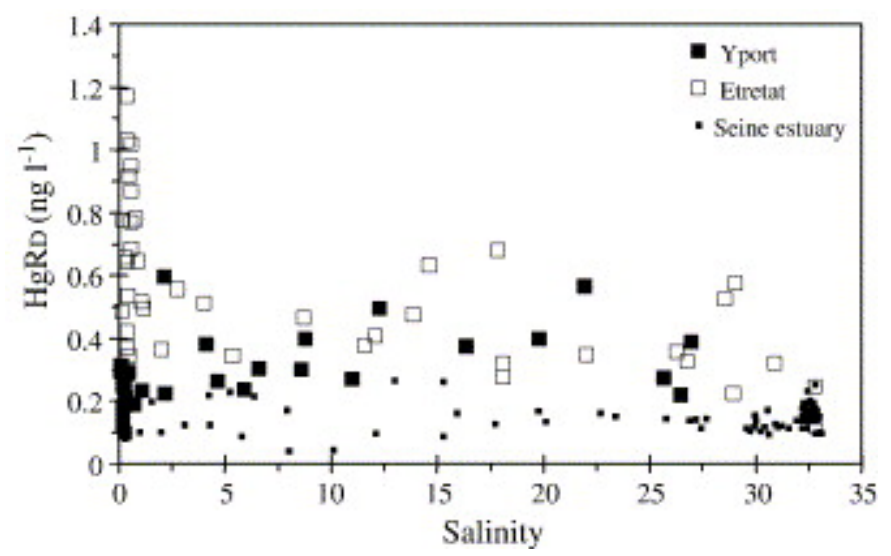

Figure 8. Reactive dissolved mercury $\left(\mathrm{HgR}_{\mathrm{D}}\right)$ concentrations for Etretat, Yport and the Seine estuary in relation to salinity.

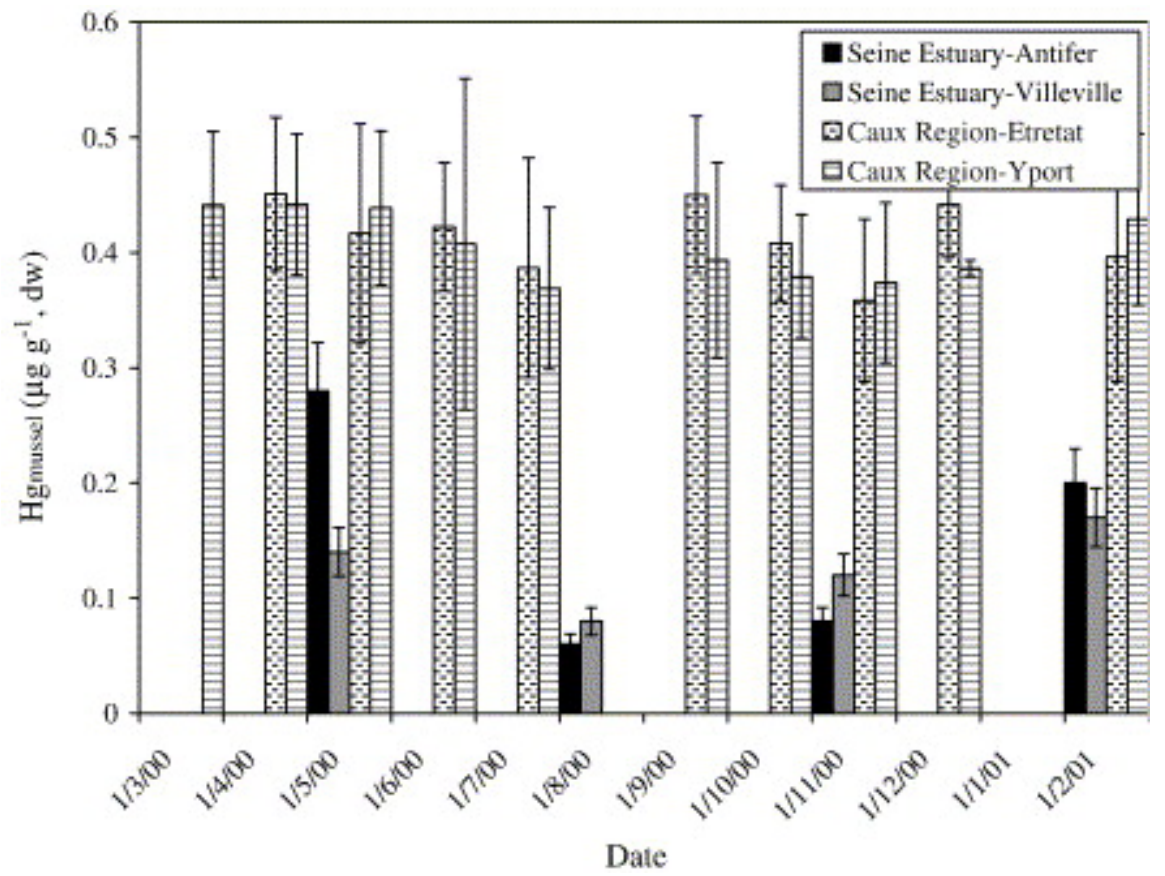

Figure 9. Mercury concentrations in mussel soft tissue from the Pays de Caux and the Seine estuary during the one year sampling period (March 2000-February 2001). 